\title{
ANALISIS RASIO ARUS KAS DALAM MENILAI KINERJA KEUANGAN PADA PT. PLN (PERSERO) WILAYAH SULUTTENGGO
}

\author{
Megi Sila Jona Warongan ${ }^{1}$, Ventje Ilat ${ }^{2}$, Natalia Gerungai ${ }^{3}$ \\ ${ }^{1,2,3}$ Jurusan Akuntansi, Fakultas Ekonomi dan Bisnis, Universitas Sam Ratulangi, Jl. Kampus Bahu, Manado, \\ 95115, Indonesia
}

Email : megi.warongan10@gmail.com

\begin{abstract}
Cash is one of the most liquid account compared to the other accounts within the company's balance sheet. The statements of cash flow contains information of actual cash position occurring in the company's operational activities. By using cash flow ratios, development of the company's financial performance from year to year can be analyzed. This study aims to determine and assess financial performance based on cash flow ratios in PT. PLN (Persero) Suluttenggo Region, by using a descriptive method with a quantitative approach. The results showed that the state of PT. PLN (Persero) Suluttenggo Region's financial performance is less good. This is because four of the five cash flow ratios assessed experienced a decrease from the ratio in 2014, and only the ratio of cash flow to interest in 2016 increased from the previous years. Increasing the company's cash is very important for PT. PLN (Persero) Suluttenggo Region, especially on operational activities which is the main activity of the company's cash so that in the future, the company's financial performance will get better.
\end{abstract}

Keywords: cash, cash flow ratio, cash flow statement, financial performance

\section{PENDAHULUAN}

Adanya perkembangan zaman yang diikuti berkembangnya juga sumber-sumber kekayaan alam, kemajuan ilmu pengetahuan, dan tekonologi membuat dunia bisnis dan pelaku-pelaku bisnis di zaman ini bergerak lebih aktif dan tanggap akan segala perubahan yang terjadi. Suatu perusahaan yang ingin berkembang sudah semestinya melakukan perubahan. Di antaranya perubahan yang biasanya dilakukan perusahaan adalah mengenai kinerja yang ada dalam perusahaan, terutama kinerja keuangan atau profitabilitas. Profitabilitas perusahaan akan terlihat dari laporan keuangan perusahaanInformasi tentang arus kas suatu perusahaan berguna bagi pemakai laporan keuangan sebagai dasar untuk menilai kemampuan perusahaan dalam menghasilkan kas dan setara kas juga menilai kebutuhan perusahaan untuk menggunakan arus kas tersebut. Oleh sebab itu, untuk menganalisis kinerja suatu perusahaan sangat tepat bila digunakan informasi yang disajikan di dalam laporan arus kas.

Stevania (2012:3), analisis terhadap kinerja keuangan perusahaan dilakukan untuk mengetahui kondisi keuangan perusahaan. Analisis ini merupakan alat bantu dalam proses penilaian keadaan keuangan serta hasil usaha perusahaan. Pengukuran kinerja keuangan dilakukan dengan cara menganalisis laporan keuangan dengan menggunakan rasio-rasio keuangan perusahaan khususnya rasio arus kas.

Analisis laporan arus kas berguna dalam mengevaluasi posisi dan operasi perusahaan dan dilakukan perbandingan dengan tahun-tahun sebelumnya sehingga dapat diketahui baik tidaknya kinerja perusahaan dalam beroperasi. Setiap perusahaan dalam menjalankan operasi usahanya akan mengalami arus masuk (cash flow) dan arus kas keluar (cash out flows). 
Data laporan arus kas digunakan untuk menghitung rasio tertentu yang menggambarkan kekuatan keuangan perusahaan. analisis rasio arus kas dapat diketahui bagaimana kinerja keuangan perusahaan atas kegiatan operasi, kegiatan investasi dan kegiatan pendanaan. Rasio arus kas yang digunakan untuk menilai kinerja keuangan yaitu, Rasio Arus Kas Operasi terhadap kewajiban lancar, Rasio Arus Kas Operasi Terhadap Bunga, Rasio pengeluaran Modal (PM), Rasio Total Hutang, dan Rasio Arus Kas Terhadap Laba Bersih. PT. PLN (Persero) wilayah Suluttenggo, merupakan sebuah BUMN yang mengurusi semua aspek kelistrikan. PT. PLN (Persero) wilayah Suluttenggo berpedoman pada visi dan misinya melakukan perlindungan terhadap pelanggan dengan melaksanakan prioritas layanan kepada masyarakat. Oleh sebab itu dilakukan analisis terhadap laporan keuangan khususnya laporan arus kas untuk menilai kinerja keuangan perusahaan menggunakan rasio arus kas.

\section{TINJAUAN PUSTAKA}

\subsection{Akuntansi}

Akuntansi Secara umum, akuntansi dapat didefinisikan sebagai sebuah sistem informasi yang memberikan laporan kepada para pengguna informasi akuntansi atau kepada pihakpihak yang memiliki kepentingan (stakeholders) terhadap hasil kinerja dan kondisi keuangan perusahaan. Menurut Kartikahadi (2015:3), Akuntansi adalah suatu sistem informasi keuangan yang bertujuan untuk menghasilkan dan melaporakan informasi yang relevan bagi berbagai pihak yang berkepentingan.

\subsection{Akuntansi Keuangan}

Akuntansi keuangan merupakan proses yang berpuncak pada penyiapan laporan keuangan perusahaan secara menyeluruh untuk digunakan oleh pihak internal dan eksternal perusahaan dalam rangka pengambilan keputusan (Santoso, 2014:15). Bidang akuntansi keuangan membahas prinsip, standar, metode, dan prosedur akuntansi untuk menghasilkan laporan keuangan yang ditunjukkan kepada pihak luar.

\subsection{Kas dan Setara Kas}

Setara kas (cash equivalent) adalah investasi yang sifatnya sangat likuid, berjangka pendek dan dengan cepat dijadikan sebagai kas dalam jumlah tertentu tanpa menghadapi resiko perubahan nilai yang signifikan. Kas merupakan komponen asset (asset) lancar yang paling likuid di dalam neraca karena kas sering mengalami mutasi atau perpindahan dan hampir semua transaksi yang terjadi dalam perusahaan akan mempengaruhi posisi kas.

\subsection{Laporan Keuangan}

Menurut Hery (2014:3), laporan keuangan merupakan produk akhir dari serangkaian proses pencatatan dan pengikhtisaran data transaksi bisnis. Seorang akuntan diharapkan mampu untuk mengorganisir seluruh data akuntansi hingga menghasilkan laporan keuangan dan bahkan harus dapat menginterpretasikan serta menganalisis laporan keuangan yang dibuatnya. Menurut Ardiyos (2016:213) Laporan Keuangan merupakan proses berkala yaitu menampilkan data-data keuangan tentang posisi suatu perusahaan, kinerja operasi, dan aliran dana-dana selama periode akuntansi untuk pihak-pihak di luar organisasi bisnis.

\section{Tujuan Laporan Keuangan}

Hery (2014:4), tujuan keseluruhan dari laporan keuangan adalah untuk memberikan informasi bagi investor dan kreditor dalam pengambilan keputusan investasi dan kredit. Investor sangat berkepentingan terhadap laporan keuangan yang disusun investee terutama dalam hal pembagian dividen, sedangkan kreditor berkepentingan dalam hal pengembalian jumlah pokok pinjaman berikut bunganya.

\section{Komponen Laporan Keuangan}

Laporan keuangan yang lengkap terdiri dari komponen-komponen berikut ini : (1) Neraca (laporan posisi keuangan pada akhir periode) ; (2) Laporan laba rugi; (3) Laporan 
perubahan ekuitas; (4) Laporan arus kas; (5) catatan atas laporan keuangan. Berikut ini merupakan penjelasan mengenai komponen-komponen laporan keuangan.

\subsection{Laporan Arus Kas}

Menurut PSAK No.2 (IAI 2015:120), laporan arus kas adalah laporan atas arus kas masuk dan arus kas keluar atau setara kas, laporan arus kas harus melaporkan arus kas selama periode tertentu dan diklasifikasi menurut aktivitas operasi, investasi dan pendanaan.

Laporan arus kas merupakan suatu revisi dari mana uang kas yang diperoleh perusahaan dan bagaimana mereka membelanjakannya. Laporan arus kas merupakan ringkasan dari penerimaan kas dan pengeluaran kas perusahaan selama periode tertentu.

\section{Jenis Aliran Kas}

Ajeng (2014:183), aliran kas dibedakan menjadi dua macam, yaitu aliran kas masuk (inflow) dan aliran kas keluar (outflow). Dua jenis aliran ini akan memberikan pengaruh berbeda terhadap posisi atau nilai kas. Arus kas masuk akan menambahkan jumlah kas, sedangkan arus kas keluar akan mengurangi nilai atau jumlah kas. Arus kas masuk atau keluar tentu disebabkan oleh aktivitas tau transaksi tertentu.

\section{Kegunaan Informasi Arus Kas}

laporan arus kas tentunya dapat memberikan informasi penting bagi para pemakai untuk mengevaluasi perubahan yang ada dalam struktur keuangan (termasuk likuiditas dan solvabilitas), aktiva bersih perusahaan, dan kemampuan dalam mempengaruhi jumlah serta waktu arus kas dalam beradaptasi dengan perubahan keadaan dan peluang. Di samping itu, informasi arus kas juga berguna sebagai indikator pada jumlah arus kas dimasa yang akan datang, dan untuk menilai kecermatan atas taksiran arus kas yang telah dibuat sebelumnya.

\section{Klasifikasi Arus Kas}

Hery (2014:89), dalam laporan arus kas, penerimaan dan pembayaran kas diklasifikasikan menurut tiga kategori utama, yaitu aktivitas operasi, investasi, dan pembiayaan.

\section{Aktivitas Operasi}

Arus kas yang paling utama dari perusahaan adalah terkait dengan aktivitas operasi. Aktivitas operasi meliputi transaksi-transaksi yang tergolong sebagai penentu besarnya laba/rugi bersih.

2. Aktivitas Investasi

Yang termasuk sebagai aktivitas investasi adalah membeli atau menjual tanah, bangunan, dan peralatan. Di samping itu, aktivitas investasi juga meliputi pembelian dan penjualan instrument keuangan yang bukan untuk tujuan diperdagangkan (non trading securities), penjualan segmen bisnis, dan pemberian pinjaman kepada entitas lain, termasuk penagihannya.

3. Aktivitas Pembiayaan

Yang termasuk kedalam aktivitas pembiayaan adalah meliputi transaksi-transaksi yang berkaitan dengan utang jangka panjang maupun ekuitas (modal) perusahaan. Pembayaran utang lancar tidak tergolong sebagai aktivitas pembiayaan, melainkan aktivitas operasi.

\section{Bentuk Laporan Arus Kas}

Menurut Hery (2014:89), ada dua metode yang digunakan dalam melaporkan dan menghitung jumlah arus kas bersih dari aktivitas operasi, metode langsung (Direct Method) dan metode tidak langsung (Indirect Methhod). Baik metode langsung maupun metode tidak langsung akan menghasilkan angka kas yang sama, yaitu jumlah arus kas bersih yang sama yang dihasilkan oleh aktivitas operasi perusahaan.

\section{Pengukuran dan Analisis Kinerja Keuangan}

Analisis kinerja keuangan merupakan suatu proses pengkajian kinerja keuangan secara kritis, yang meliputi peninjauan data keuangan, penghitungan, pengukuran, interpretasi, dan 
pemberian solusi terhadap masalah keuangan perusahaan pada suatu periode tertentu. Dalam penelitian ini, alat analisis yang digunakan untuk menilai kondisi dan kinerja keuangan perusahaan adalah hasil rasio keuangan yang menghubungkan dua data keuangan dengan jalan membagi suatu data dengan data lainnya. Rasio keuangan ini diperoleh atau dihitung dari laporan keuangan yang dihasilkan merupakan ikhtisar mengenai keuangan suatu perusahaan. Sehingga, rasio yang akan digunakan untuk menilai kinerja keuangan berdasarkan laporan arus kas adalah rasio arus kas.

\subsection{Rasio Arus Kas}

Salah satu analisis keuagan dengan menggunakan informasi laporan arus kas adalah analisis rasio laporan arus kas dan komponen neraca dan laporan laba rugi sebagai informasi dalam analisis rasio (Herry, 2015:124), rasio laporan arus kas yang dimaksud terdiri atas:

1. Rasio Arus Kas Operasi Terhadap Kewajiban Lancar

2. Rasio Arus Kas Operasi terhadap Bunga

3. Rasio Pengeluaran Modal

4. Rasio Total Hutang

5. Rasio Arus Kas terhadap Laba Bersih

\subsection{Manfaat Kinerja Keuangan}

Dalam Susanti (2017:22), adapun manfaat dari penilaian kinerja adalah sebagai berikut:

a) Mengukur prestasi yang dicapai suatu organisasi dalam suatu periode tertentu

b) Pengukuran kinerja juga dapat digunakan untuk menilai kontribusi suatu bagian dalam pencapaian tujuan perusahaan secara keseluruhan.

c) Dapat digunakan sebagai dasar penentuan strategi perusahaan untuk masa yang akan datang.

d) Memberikan petunjuk dalam pembuatan keputusan

e) Dasar penentuan kebijaksanaan penanaman modal agar dapat meningkatkan produktivitas dan efektivitas perusahaan.

\subsection{Penelitian Terdahulu}

1. Penelitian oleh Herlina T. Dareho (2016), dalam skripsinya berjudul "Analisis laporan arus kas untuk menilai kinerja keuangan pada PT. Ace Hardware Indonesia, Tbk". Penelitian dari ini memiliki tujuan Untuk mengetahui analisis laporan arus kas dan kinerja keuangan PT. Ace Hardware Indonesia, Tbk. Metode penelitian yang digunakan dalam penelitian ini adalah Deskriptif Kualitatif. Hasil penelitian yang diperoleh dari penelitian ini adalah Perusahaan mengalami kinerja keuangan yang tidak stabil. Walupun belum semua rasio, namun jika dilihat secara keseluruhan kinerja keuangan perusahaan semakin membaik pada periode akuntansi tahun 2014 karena terjadi peningkatan. Persamaan dengan penelitian ini adalah Menganalisis kinerja keuangan dengan menggunakan rasio arus kas. Perbedaannya adalah terdapat pada obejek penelitian.

2. Penelitian oleh Susanti Tudje (2017), dalam skripsinya berjudul "Analisis Laporan Arus Kas sebagai Alat Ukur Kinerja Keuangan pada Perusahaan Concumer Goods Industry Di Bursa Efek Indonesia". Penelitian dari ini memiliki tujuan Untuk mengetahui dan menilai kinerja keuangan berdasarkan analisis laporan arus kas pada perusahaan Consumer Goods Industry. Metode penelitian yang digunakan dalam penelitian ini adalah Deskriptif Kualitatif. Hasil penelitian yang diperoleh dari penelitian ini adalah Perusahaan Consumer Goods Industry, memiliki kinerja yang kurang baik. Hal ini dapat dilihat dari hasil analisis dengan menggunakan arus kas dimana semua hasil perhitungan mendapatkan hasil yang kurang baik. Persamaan dengan penelitian ini adalah Melakukan penelitian terhadap satu variable yang sama yaitu laporan arus kas. Perbedaannya adalah Peneliti hanya melakukan analisis melakukan rasio arus kas saja. 


\section{METODE PENELITIAN}

\subsection{Jenis Penelitian}

Jenis penelitian yang digunakan adalah penelitian deskriptif dengan melakukan pendekatan kuantitatif.

\subsection{Tempat dan waktu Penelitian}

Tempat Penelitian pada PT. PLN (Persero) wilayah Suluttenggo yang berlokasi di Jalan Bethesda nomor 32 Kota Manado, Sulawesi Utara. Waktu penelitian dimulai pada bulan Februari sampai April tahun 2018.

\subsection{Metode Pengumpulan Data}

\section{Jenis Data}

Dalam penelitian ini, digunakan data kuantitatif yaitu berupa laporan keuangan perusahaan pada PT. PLN (Persero) wilayah Suluttenggo tahun 2014, 2015, dan 2016.

\section{Sumber Data}

Data primer pada penelitian ini berupa data laporan keuangan PT. PLN (Persero) wilayah Suluttenggo tahun 2014,2015 dan 2016, dan data berupa hasil wawancara dengan pihak perusahaan. Data sekunder pada penelitian ini adalah berupa data ikhtisar kebijakan akuntansi perusahaan yang berhubungan dengan laporan arus kas.

\section{Teknik Pengumpulan Data}

1. Penelitiaan Lapangan (field Research)

2. Riset Kepustakaan (Library Research)

3. Media Elektronik

\subsection{Metode Analisis}

Metode yang dipakai dalam penelitian ini adalah metode analisis deskriptif dengan pendekatan kuantitatif, ialah menjelaskan hasil penelitian yang berupa data-data laporan keuangan yang berhubungan dengan laporan arus kas terhadap kinerja keuangan perusahaan.

\section{HASIL ANALISIS DAN PEMBAHASAN}

4.1. Hasil Penelitian

\section{Rasio Arus Kas Operasi terhadap Kewajiban Lancar}

$$
\text { Rasio arus kas operasi }=\frac{\text { Arus kas operasi }}{\text { Kewajiban lancar }}
$$

Tahun 2014

Rasio arus kas operasi terhadap kewajiban lancar

$$
\begin{array}{cc}
= & \frac{R p \cdot 39.252 .442}{R p \cdot 87.558 .279} \\
= & 0.45
\end{array}
$$

\section{Tahun 2015}

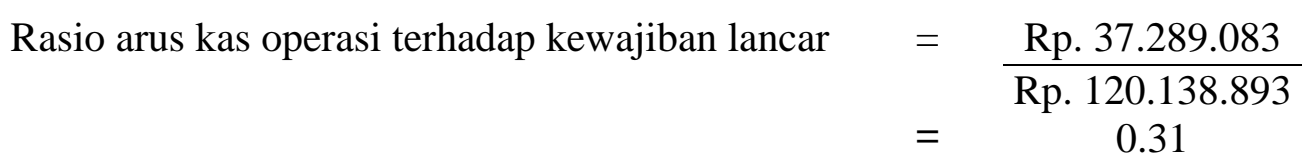




\section{Tahun 2016}

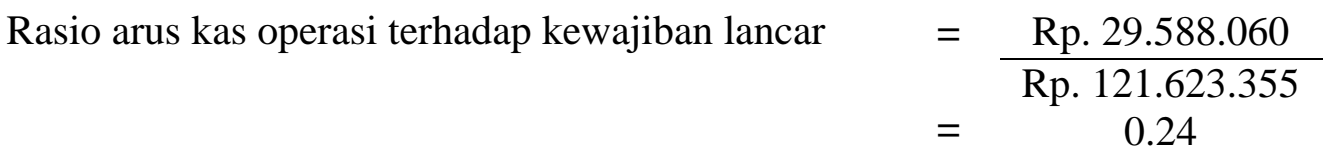

\section{Rasio Arus Kas Operasi Terhadap Bunga}

Rasio arus kas operasi terhadap bunga $=\frac{\text { Arus kas operasi }+ \text { bunga }+ \text { pajak }}{\text { Bunga }}$

\section{Tahun 2014}

Rasio arus kas operasi terhadap Bunga

$=\frac{\text { Rp. 39.252.442+Rp. 35.381.682+Rp. } 1.704 .744}{\text { Rp. 35.381.682 }}$
$=2.16$

\section{Tahun 2015}

Rasio arus kas operasi terhadap Bunga

$=\frac{\text { Rp. 37.289.083+Rp. } 37.708 .595+R p \cdot 3.789 .944}{\text { Rp. } 37.708 .595}$
$=2.09$

Tahun 2016

Rasio arus kas operasi terhadap Bunga

$=\frac{\text { Rp. } 29.588 .060+R p \cdot 18.285 .840+R p \cdot 1.927 .652}{\text { Rp. } 18.285 .840}$
$=2.72$

\section{Rasio Arus Kas Operasi Terhadap Pengeluaran Modal}

$$
\text { Rasio pengeluaran modal }=\frac{\text { Arus kas operasi }}{\text { Pengeluaran modal }}
$$

Tahun 2014

Rasio arus kas operasi terhadap pengeluaran modal $=\frac{\text { Rp. 39.252.442 }}{\text { Rp. 30.132.270 }}$

$$
=\quad 1.30
$$




\section{Tahun 2015}

Rasio arus kas operasi terhadap pengeluaran modal $=\frac{\text { Rp. } 37.289 .083}{\text { Rp. 36.365.403 }}$

$$
=\quad 1.02
$$

\section{Tahun 2016}

Rasio arus kas operasi terhadap pengeluaran modal

$$
\begin{array}{cc}
= & \text { Rp. } 29.588 .060 \\
= & \text { Rp. } 55.800 .543 \\
0.53
\end{array}
$$

\section{Rasio Arus Kas Operasi Terhadap Total Utang}

$$
\text { Rasio total utang }=\frac{\text { Arus kas operasi }}{\text { Total utang }}
$$

\section{Tahun 2014}

Rasio arus kas operasi terhadap total utang $=\frac{\text { Rp. 39.252.442 }}{\text { Rp. 454.144.509 }}$

$$
=0.086
$$

\section{Tahun 2015}

Rasio arus kas operasi terhadap total utang $=\frac{\text { Rp. 37.289.083 }}{\text { Rp. 509.580.264 }}$

$$
=0.073
$$

\section{Tahun 2016}

Rasio arus kas operasi terhadap total utang $=\frac{\text { Rp. 29.588.060 }}{\text { Rp. 393.778.518 }}$

$$
=\quad 0.075
$$

\section{Rasio Arus Kas Operasi Terhadap Laba Bersih}

$$
\text { Rasio arus kas terhadap laba bersih }=\frac{\text { Arus kas operasi }}{\text { Laba bersih }}
$$

\section{Tahun 2014}

Rasio arus kas operasi terhadap laba bersih $=\frac{\text { Rp. 39.252.442 }}{\text { Rp. } 15.004 .069}$

$$
=\quad 2.61
$$

\section{Tahun 2015}

Rasio arus kas operasi terhadap laba bersih $=\frac{\text { Rp. } 37.289 .083}{\text { Rp. } 15.913 .435}$

$$
=\quad 2.34
$$




\section{Tahun 2016}

Rasio arus kas operasi terhadap laba bersih $=\frac{\text { Rp. } 29.588 .060}{\text { Rp. 13.578.226 }}$

\subsection{Pembahasan}

$$
=\quad 2.18
$$

\section{Rasio arus kas operasi terhadap kewajiban lancar}

Tabel 1. Rasio Kewajiban Lancar

\begin{tabular}{|c|c|c|c|}
\hline Tahun & Arus Kas Operasi & Kewajiban Lancar & Rasio \\
\hline 2014 & Rp. 39.252.442 & Rp. 87.558.279 & 0.45 \\
\hline 2015 & Rp. 37.289.083 & Rp. 120.138.893 & 0.31 \\
\hline 2016 & Rp. 29.588.060 & Rp. 121.623.355 & 0.24 \\
\hline
\end{tabular}

Hasil analisis rasio tersebut menunjukkan bahwa rasio kewajiban lancar tertinggi terjadi pada tahun 2014 dan mengalami penurunan pada tahun 2016 dengan perbedaan angka 0.07 dibandingkan dengan tahun 2015. Dalam penelitian ini, angka rasio kewajiban lancar tahun 2014, 2015, dan 2016 berada pada angka rasio di bawah 1, maka dapat disimpulkan rasio kewajiban lancar PT. PLN (Persero) Wilayah Suluttenggo adalah kurang baik, sehingga perusahaan tidak mampu melunasi kewajiban lancarnya hanya dengan menggunakan arus kas operasi saja.

\section{Rasio arus kas operasi terhadap bunga}

Tabel 2. Rasio Bunga

\begin{tabular}{|c|c|c|c|c|}
\hline Tahun & Arus Kas Operasi & Bunga & Pajak & Rasio Bunga \\
\hline 2014 & Rp. 39.252 .442 & Rp. 35.381.682 & Rp. 1.704.744 & 2.16 \\
\hline 2015 & Rp. 37.289 .083 & Rp. 37.708.595 & Rp. 3.789.944 & 2.09 \\
\hline 2016 & Rp. 29.588 .060 & Rp. 18.285.840 & Rp. 1.927.652 & 2.72 \\
\hline
\end{tabular}

Hasil perhitungan di atas, dapat disimpulkan bahwa berdasarkan rasio arus kas terhadap bunga pada PT. PLN (Persero) Wilayah Suluttenggo tahun 2014, 2015, dan 2016 menunjukkan angka rasio yang tinggi yaitu di atas 1, sehingga untuk dapat menutup biaya bunga bisa langsung membayarnya tanpa harus menjual aktiva atau menunggu penagihan piutang, karena kas operasi yang tersedia mampu untuk membayarnya.

\section{Rasio arus kas operasi terhadap pengeluaran modal}

Tabel 3. Rasio Pengeluaran Modal

\begin{tabular}{|c|c|c|c|}
\hline Tahun & Arus Kas Operasi & Pengeluaran Modal & Rasio \\
\hline 2014 & Rp. 39.252 .442 & Rp. 30.132 .270 & 1.30 \\
\hline 2015 & Rp. 37.289 .083 & Rp. 36.365 .403 & 1.02 \\
\hline 2016 & Rp. 29.588 .060 & Rp. 55.800 .543 & 0.53 \\
\hline
\end{tabular}

Hasil perhitungan tersebut, menunjukkan bahwa rasio pengeluaran modal PT. PLN (Persero) wilayah Suluttenggo adalah cukup baik, walaupun terjadi penurunan angka rasio pada tahun 2016, namun pada tahun 2014 dan 2015 menunjukkan bahwa angka rasio berada di atas 1. Dilihat dari rasio pengeluaran modal pada tahun 2014 dan tahun 
2015 menunjukkan perusahaan memiliki kemampuan yang cukup baik dalam membiayai pengeluaran modal perusahaan, sehingga tidak perlu menunggu pendanaan eksternal seperti kreditor dan investor.

4. Rasio arus kas operasi terhadap total utang

Tabel 4. Rasio Total Utang

\begin{tabular}{|c|c|c|c|}
\hline Tahun & Arus Kas Operasi & Total Utang & Rasio \\
\hline 2014 & Rp. 39.252 .442 & Rp. 454.144.509 & 0.086 \\
\hline 2015 & Rp. 37.289 .083 & Rp. 509.580.264 & 0.073 \\
\hline 2016 & Rp. 29.588 .060 & Rp. 393.778.518 & 0.075 \\
\hline
\end{tabular}

Hasil perhitungan rasio total utang di atas menunjukkan bahwa rasio total utang PT. PLN (Persero) wilayah Suluttenggo adalah kurang baik, karena angka rasio total utang tahun 2014-2015 berada di bawah 1 namun angka tertinggi ada pada tahun 2014. Dapat dikatakan, bahwa perusahaan tidak memiliki kemmapuan yang baik dalam membayar semua kewajibannya dengan menggunakan arus kas yang berasal dari aktivitas normal operasi perusahaan.

\section{Rasio arus kas operasi terhadap laba bersih}

Tabel 5. Rasio Laba Bersih

\begin{tabular}{|c|c|c|c|}
\hline Tahun & Arus Kas Operasi & Laba Bersih & Rasio \\
\hline 2014 & Rp. 39.252 .442 & Rp. 15.004.069 & 2.61 \\
\hline 2015 & Rp. 37.289 .083 & Rp. 15.913.435 & 2.34 \\
\hline 2016 & Rp. 29.588.060 & Rp. 13.578.226 & 2.18 \\
\hline
\end{tabular}

Hasil perhitungan di atas menunjukkan bahwa rasio laba bersih PT. PLN (Persero) wilayah Suluttenggo dapat dikatakan cukup baik karena tahun 2014,2015, dan 2016 posisi angka rasio adalah di atas 1 . Walaupun dari tahun ke tahun mengalami penurunan angka rasio, namun dilihat dari angka rasio yang berada di atas 1 dapat menunjukkan bahwa kinerja keuangan perusahaan semakin baik.

\section{KESIMPULAN DAN SARAN}

\subsection{Kesimpulan}

Dari hasil analisis rasio arus kas yang telah dilakukan pada PT. PLN (Persero) wilayah

Suluttenggo selama tahun 2014-2016, maka diperoleh hasil sebagai berikut.

1. Rasio Arus Kas Operasi terhadap Kewajiban Lancar pada PT. PLN (Persero) wilayah Suluttenggo selama tahun 2014-2016 belum maksimal. Dapat dikatakan perusahaan tidak mampu melunasi kewajiban lancarnya hanya dengan menggunakan arus kas berdasarkan aktivitas operasi perusahaan.

2. Rasio Arus Kas Operasi terhadap Bunga menunjukkan PT.PLN (Persero) Wilayah Suluttenggo tidak harus menjual aktiva atau menunggu penagihan piutang, karena arus kas dalam aktivitas operasi yang tersedia mampu untuk membayar atau menutup biaya bunga.

3. Rasio Arus Kas Operasi terhadap Pengeluaran Modal menunjukkan PT. PLN (Persero) Wilayah Suluttenggo memiliki kemampuan cukup baik dalam membiayai pengeluaran modal perusahaan, sehingga tidak perlu menunggu pendanaan eksternal.

4. Rasio Arus Kas Operasi terhadap Total Utang menunjukkan PT.PLN (Persero) Wilayah Suluttenggo tidak memiliki kemampuan yang baik dalam membayar semua 
kewajibannya dengan menggunakan arus kas yang berasal dari aktivitas normal operasi perusahaan.

5. Rasio Arus Kas Operasi terhadap Laba Bersih menunjukkan kinerja PT. PLN (Persero) Wilayah Suluttenggo dapat dikatakan semakin baik, karena selama tahun 2014-2016 memiliki angka rasio arus kas operasi terhadap laba bersih yang berada diatas 1 walaupun menurun setiap tahunnya.

Berdasarkan hasil penelitian, maka dapat diambil kesimpulan laporan arus kas PT. PLN (Persero) selama tahun 2014, 2015, dan 2016 angka rasio yang didapatkan dari hasil analisis secara umum cukup baik yaitu lebih dari satu, meskipun demikian kinerja keuangan perusahaan PT. PLN (Persero) wilayah Suluttenggo kurang baik. Hal ini dikarenakan empat dari lima rasio arus kas yang dinilai mengalami penurunan dari angka rasio pada tahun 2014, dan hanya rasio arus kas terhadap bunga yang pada tahun 2016 mengalami peningkatan dari tahun- tahun sebelumnya.

\subsection{Saran}

Berdasarkan kesimpulan yang telah disajikan di atas, dapat dikemukakan saran yang diharapkan dapat menambah informasi dan membantu bagi pihak PT. PLN (Persero) wilayah Suluttenggo, ataupun pihak-pihak luar yang berkepentingan. Untuk mencapai tujuan yang telah ditetapkan perusahaan dan meningkatkan kinerja perusahaan, maka disarankan bagi PT. PLN (Persero) wilayah Suluttenggo untuk lebih meningkatkan kas perusahaan terlebih pada aktivitas operasi yang merupakan aktivitas utama perusahaan dan mengurangi jumlah hutang agar kedepannya arus kas perusahaan semakin meningkat.

\section{DAFTAR PUSTAKA}

Albertus, Indratno. 2013. Prinsip-Prinsip Dasar Akuntansi. Dunia Cerdas. Jakarta.

Ahmad, Syakur. 2015. Intermediate Accounting. Edisi Revisi, Pembuka Cakrawala, Jakarta. Ajeng, Wind. 2014. Buku Saku Akuntansi. Laskar Raksara. Jakarta.

Andre, Wehantouw. 2015. Analisis Laporan Arus Kas Operasi, Investasi dan Pendanaan Pada PT. Gudang Garam Tbk. Jurnal EMBA. Vol. 3 No.1. Fakultas Ekonomi. Universitas Sam Ratulangi. Manado. Hal 806-817.

Hendry, Andres Maith. 2013. Analisis Laporan Keuangan dalam Mengukur Kinerja Keuangan pada PT. Hanjaya Mandala Sampoerna Tbk. Jurnal. Vol 1 No 3 Hal 619628. Universitas Sam Ratulangi Manado.

Herlina, Dareho. 2016. Analisis Laporan Arus Kas untuk Menilai Kinerja Keuangan pada PT. Ace Hardware Indonesia, Tbk. Vol 4 No 2. Fakultas Ekonomi Universitas Sam Ratulangi. Hal 662-672

Hery. 2014. Analisis Kinerja Manajemen. PT. Grasindo. Jakarta.

Hery. 2015. Analisis Laporan Keuangan. Center For Academic Publishing Service. Yogyakarta.

Hery. 2015. Pengantar Akuntansi. Comprehensive Edition. PT. Grasindo. Jakarta.

Kartikahadi, Hans., Sinaga, Uli Rosita., Syamsul, Merliyana., Siregar, Sylvia Veronica., Wahyuni, Ersa Tri.2015. Akuntansi Keuangan Berdasarkan SAK Berbasis IFRS. Edisi Kedua. Buku 1. Penerbit Ikatan Akuntan Indonesia. Jakarta.

Kasmir. 2015. Analisis Laporan Keuangan. PT. Grafindo Persada. Jakarta.

Romy, Mansaleo. 2016. Evaluasi Penerapan Laporan Arus Kas Berdasarkan PSAK No.2 pada Perusahaan Perbankan yang Terdaftar di Bursa Efek Indonesia (BEI). Jurnal. Vol 16 No 4. Universitas Sam Ratulangi Manado. Hal 962- 970. 
Rudianto. 2012. Pengantar Akuntansi, Konsep dan Teknik Penyusunan Laporan Keuangan. Penerbit Erlangga. Jakarta.

Sri, Mulyani. 2013. Analisis Rasio Arus Kas Sebagai Alat Pengukur Kinerja Keuangan Perusahaan. STIE Pariwisata Semarang.

Stevania, S. Pandelaki. 2012. Analisis Penggunaan Laporan Arus Kas dalam Menilai Kinerja Keuangan pada PT. Kimia Farma (Persero) Tbk. Skripsi (Tidak Dipublikasikan). Universitas Sam Ratulangi.

Susanti, Tudje. 2017. Analisis Laporan Arus Kas sebagai Alat Ukur Kinerja Keuangan pada Perusahaan Consumer Goods Industry di Bursa Efek Indonesia. Fakultas Ekonomi dan Bisnis Universitas Sam Ratulangi.

Sofyan, Harahap. 2016. Analisis Kritis atas Laporan Keuangan. PT Raja Grafindo Persada. Jakarta.

Subani, 2015. Analisis Arus Kas untuk Mengukur Kinerja Keuangan (Studi pada KUD Sido Makmur Lumanjang). Jurnal WIGA. Vol. 5 No. 1 Maret 2015. STIE Widya Gama Lumanjang. Diakses 10 Desember 2017. Hal 58-67. 